\title{
Pengaruh Daya Beli Masyarakat dan Strategi Pemasaran Dalam Meningkatkan Hasil Penjualan Pada Bisnis Property
}

\author{
Johan Budiman \\ Teknik Sipil, Fakultas Teknik, Universitas Islam Syekh Yusuf, Jl. Mulana Yusuf No.10 Tangerang Banten 15118, \\ Indonesia \\ joebudiman@unis.ac.id
}

\begin{abstract}
Abstrak. Bisnis properti di Indonesia telah berkembang semakin pesat, baik di Jakarta, Bandung, Surabaya dan beberapa kota besar lainnya, tetapi saat ini banyaknya property yang sedang menghadapi masalah resiko pasar (market risk) dan resiko likuiditas (liquidity risk). Tujuan penelitian ini adalah : untuk mengetahui adanya pengaruh yang positif antara daya beli masyarakat dalam meningkatkan hasil penjualan pada bisnis property, untuk mengetahui adanya pengaruh yang positif antara strategi pemasaran dalam meningkatkan hasil penjualan pada bisnis property. Dari hasil analisis pada tabel uji ANOVA atau nilai $F_{\text {test }}$ di dapati nilai $F_{\text {hitung }}$ sebesar 26,653. Sedang $F_{\text {tabel }}$ $(\propto 0.05)$ untu $N=30$ adalah sebesar 0,29. Jadi $F_{\text {hitung }}>F_{\text {tabel }}(\propto 0.05)$ atau 26,653 $>0,29$, maka dapat dikatakan bahwa daya beli $\left(X_{I}\right)$ dan strategi pemasaran $\left(X_{2}\right)$ secara bersama-sama memang berpengaruh positif dan signifikan terhadap hasil penjualan (Y), nilai $R$ (Index Determinasi) sebesar 0,815 . Hal ini menunjukan bahwa sebesar $81,5 \%$ pelayanan $\left(X_{1}\right)$ dan komunikasi $\left(X_{2}\right)$ secara simultan (bersama-sama) berpengaruh terhadap kepuasan pelanggan sedangkan sisanya sebesar 18,5\% berhubungan dengan factor lainnya yang tidak teramati oleh penulis.
\end{abstract}

Kata kunci: daya beli, bisnis property, market risk

Abstract. [Title in English: Please Type Title of Article in English in here and Bold formated]. Property business in Indonesia has grown rapidly, both in Jakarta, Bandung, Surabaya and several other big cities, but currently many properties are facing market risk and liquidity risk. The purpose of this study is: to know the existence of a positive influence between the purchasing power of the community in increasing the sale of the property business, to know the existence of a positive influence between marketing strategies in increasing the sales results on the property business. From the results of the analysis on the ANOVA test tabel or Ftest value found in Fcount of 26.653. Medium Ftabel $(\alpha 0.05)$ for $N=30$ is 0.29. So Fcount $>$ Ftabel $(\alpha 0.05)$ or $26.653>0.29$, it can be said that the purchasing power $\left(X_{1}\right)$ and marketing strategy $\left(X_{2}\right)$ together do have a positive and significant effect on sales revenue $(Y), R$ Determination) of 0.815 . This shows that $81.5 \%$ of service $\left(X_{1}\right)$ and communication $\left(X_{2}\right)$ simultaneously affect the customer satisfaction while the remaining $18.5 \%$ is related to other factors not observed by the author.

Keywords: buying power, business property, market risk

\section{Pendahuluan}

Dunia kini menghadapi era baru yang ditandai dengan kecenderungan globalisasi dunia sebagai akibat semakin banyaknya Negara yang melaksanakan liberalisasi /reformasi ekonomi yang ditunjang pula dengan majunya teknologi komunikasi dan transfortasi. Begitu pula dengan perkembangan persaingan bisnis di Indonesia, terutama pada masa satu decade terakhir ini, semakin kompetitif dan komperatif, baik dengan investor domestic maupun asing, sejalan dengan arus globalisasi yang harus terjadi.
Bisnis property di Indonesia telah berkembang semakin pesat baik di Jakarta, Bandung, Surabaya dan beberapa kota besar lainnya, seiring dalam pemenuhan kebutuhan-kebutuhan fisik suatu kota besar. Pada masa pemerintahan presiden soeharto, bisnis property di Indonesia bias dikatakan telah meroket, yang ditandai dengan laju rata-rata pertumbuhan kreditor sector property kurang lebih sebesar 39,3\% pertahun, jauh diatas laju rata-rata kredit perbankkan secara nasional yang sebesar $22,6 \%$ pertahun. Laju pertumbuhan kredit sector property ini juga diatas laju rata-rata pertumbuhan sector perdagangan dan sector perindustrian. Dari laju dan pangsa kredit tersebut 


\section{Jurnal Keilmuan dan Aplikasi Teknik \\ UNISTEK, 2018, Edisi 5, No.1}

jelaslah bahwa dari sisi moneter perkembangan bisnis property selama masa itu telah berada jauh diatas proporsi wajar, baik secara sektoral maupun secara kredit perbankan.

Tetapi pada perkembangannya setelah masa pemerintahan presiden soeharto berakhir, besar laju rata-rata pertumbuhan kredit sector bisnis property ini telah membuat kredit bermasalah yang berpotensi macet, karena banyaknya property yang sedang menghadapi masalah resiko pasar (market risk) dan resiko likuiditas (liquidity risk). Terjadinya krisis ekonomi yang berkepanjangan mengakibatkan saatsaat yang sulit bagi msyarakat dan pemasar.

Dari resiko pasar banyaknya persediaan fisik sector property yang dilakukan oleh para investor, baik berupa fisik mentah maupun yang siap dipasarkan telah memberi kemungkinan timbulnya kejenuhan pasar sehingga dikenai bunga bank akibat kredit. Ditambah lagi daya beli masyarakat yang sudah melemah yang akan mengakibatkan resiko likuiditas. Ditambah lagi dengan kondisi geografis Indonesia saat iniyang sangat rentan terjadinya bencana alam seperti ; tsunami, banjir, gempa dan lain-lain, yang membuat masyarakat berfikir kembali untuk membeli sebuah rumah yang aman dari semua itu. Dan masih banyak perusahaan property yang hanya mementingkan masyarakat mampu seperti pembangunan kawasan elite yang hanya mampu dibeli oleh masyarakat tertentu.

Berdasarkan latar belakang masalah diatasdapat diketahui pentingnya upaya untuk meningkatkan hasil penjualan pada bisnis property, dapat diidentifikasi sebagai berikut :

1. Bagaimana meningkatkan kepercayaan para investor baik investor asing maupun investor domestik pada bisnis property di Indonesi?

2. Bagaimana meningkatkan strategi pemasaran sehingga mampu bersaing dan dapat meningkatkan hasil penjualan?

3. Bagaimana meningkatkan kualitas produk yang sesuai dengan permintaan masyarakat saat ini sehingga dapat meningkatkan hasil penjualan property?

4. Bagaimana meningkatkan daya beli masyarakat terhadap bisnis property?

Berdasarkan latar belakang masalah, identifikasi masalah dalam penelitian ini, maka penelitian ini dibatasi hanya pengaruh daya beli masyarakat dan strategi pemasaran dalam meningkatkan hasil penjualan pada bisnis property. Disebabkan keterbatasan kemampuan yang ada pada diri peneliti, baik segi akademis, tenaga, biaya dan waktu.

Berdasarkan latar belakang masalah, identifikasi masalah dan pembatasan masalah yang sudah dirumuskan, maka penulis merumuskan masalah sebagai berikut :

1. Apakah terdapat pengaruh positif antara daya beli masyarakat dalam meningkatkan hasil penjualan pada bisnis property?
2. Apakah terdapat pengaruh positif antara strategi pemasaran dalam meningkatkan hasil penjualan pada bisnis property?

3. Apakah terdapat pengaruh positif antara daya beli masyarakat dan strategi pemasaran secara bersama-sama dalam meningkatkan hasil penjualan pada bisnis property?

Sesuai dengan perumusan diatas, maka tujuan penelitian ini adalah untuk :

1. Mengetahui adanya pengaruh yang positif antara daya beli masyarakat dalam meningktakan hasil penjualan pada bisnis property

2. Mengetahui adanya pengaruh yang positif antara strategi pemasaran dalam meningkatkan hasil penjualan pada bisnis property

3. Mengetahui adanya pengaruh yang positif antara daya beli masyarakat dan strategi pemasaran secara bersama-sama dalam meningkatkan hasil penjualan pada bisnis property

\section{Metodologi}

Penelitian ini dilakukan pada salah satu perusahaan yang berada di Jakarta dan dilaksanakan mulai bulan Maret sampai Juni 2006. Jenis penelitian yang digunakan adalah penelitian lapangan secara studi kasus dengan menggunakan desain diskriptif kausal, untuk pemecahan suatu kasus yaitu pengaruh daya beli konsumen dan strategi pemasaran dalam meningkatkan hasil penjualan pada bisnis property.

Populasi dalam penelitian ini adalah para karyawan yang bekerja di perusahaan property yang ada di Jakarta dan para pelanggannya, sedangkan sample $50 \%$ diambil dari populasi tersebut. Dengan demikian penelitian ini menggunakan seluruh populasi sebagai subyektif penelitian atau responden.

Adapun metode pengumpulan data yang digunakan dalam penelitian ini adalah sebagai berikut:

1. Data Primer (data asli) dikumpulkan melalui cara-cara sebagai berikut :

a. Observasi (pengamatan) yaitu cara pengumpulan data melalui pencatatan secara cermat dan sistematis langsung dilokasi obyek penelitian

b. Wawancara (interview) yaitu cara pengumpulan data melalui Tanya jawab langsung dengan responden yang mengetahui obyek penelitian

2. Data Sekunder (data tersedia) dikumpulkan melalui cara :

a. Hasil penggunaan kuesioner

b. Membaca dan mempelajari laporan-laporan yang dikeluarkan oleh pobyek penelitian

c. Studi kepustakaan, yaitu dengan membaca/mempelajari buku-buku, catatan kuliah,makalah, bahan seminar.

Teknik analisa data yang digunakan adalah dengan metode statistik, yaitu :

1. Pilihan berganda dari jawaban sangat setuju dengan nilai (5), setuju (4), cukup setuju (3), kurang setuju (2), dan tidak setuju (1). Penilaian 


\section{Jurnal Keilmuan dan Aplikasi Teknik \\ UNISTEK, 2018, Edisi 5, No.1}

dengan menggunakan frekwensi, prosentasi, pembahasan dengan skor. Akhirnya hal itu menunjukan kuat tidaknya hubungan daya beli dan strategi pemasaran dengan peningkatan hasil penjualan yang dipersepsikan oleh karyawan dan para pelanggan.

2. Deskriptif analisis, yaitu membuat deskripsi secara sistematis, factual dan akurat mengenai fakta, sifat dan hubungan antar fenomena yang diteliti melalui prosentase dan skor untuk menghitung seberapa jauh daya beli konsumen dan strategi pemasaran yang dijalankan dalam meningkatkan hasil penjualan.

Untuk dapat mengukur pengaruh dari masing-masing variabel tersebut, penulis terlebih dahulu melakukan: (1) uji validasi dan reliabilitas. (2) Analisis koefisien regresi linier, (3) Uji hipotesis dengan menggunakan perhitungan program computer SPSS Versi 12.00.

a. Uji Validitas dan Reliabilitas

Pengujian validitas pada data hasil pengembalian kuesioner untuk mengetahui daya beli konsumen dan strategi pemasaran. Pengujian Reliabilitas menggunakan teknik rumus alpha dilakukan dengan membandingkan nilai koefisien korelasi dikatakan reliabel.

b. Analisis Koefisien Regresi

Berikut tahapan uji parsial (hubungan antara satu variabel $\mathrm{X}$ dengan satu variabel $\mathrm{Y}$ ), sebagai berikut:

1. Merumuskan Hipotesis Statistik

2. Menentukan Nilai Kritis

3. Menentukan Nilai $r_{\text {test }}$

4. Pengambilan Keputusan/Kesimpulan

Tahapan uji simultan (bersama-sama) untuk mengetahui hubungan semua variabel, sebagai berikut:

1. Perumusan hipotesis penelitian (hipotesis nol dan hipotesis kerja)

2. Penentuan nilai kritis

3. Penentuan nilai $r_{\text {test }}$

4. Pengambilan keputusan/kesimpulan

\section{Hasil dan Pembahasan}

1. Pengolahan dan penyajian data dari masingmasing indikator

Perolehan perhitungan data dari masing-masing indikator adalah sebagai berikut :

1) Analisis Jawaban Responden Terhadap Daya Beli (Variabel $\mathrm{X}_{1}$ )

Untuk mengetahui hasil perhitungan jawaban dari koresponden, melalui penyebaran kuesioner yang telah penulis sebarkan, dapat dilihat pada uraian masing-masing tabel berikut:

Tabel 1. Pernyataan 1

\begin{tabular}{llrrrr}
\hline & & Frequency & Percent & $\begin{array}{r}\text { Valid } \\
\text { Percent }\end{array}$ & $\begin{array}{c}\text { Cumulative } \\
\text { Percent }\end{array}$ \\
\hline \multirow{2}{*}{ Valid } & Setuju & 13 & 43.3 & 43.3 & 43.3 \\
& Sangat Setuju & 17 & 56.7 & 56.7 & 100.0 \\
& Total & 30 & 100.0 & 100.0 & \\
\hline
\end{tabular}

Sumber : Hasil jawaban dengan program computer SPSS

Dari pernyataan 1 untuk variabel daya beli (X1) dapat dijelaskan sebagai berikut:

13 responden $(43.3 \%)$ menyatakan setuju

17 responden $(56.7 \%)$ menyatakan sangat setuju

Tabel 2. Pernyataan 2

\begin{tabular}{llrrrr}
\hline & Frequency & Percent & Valid & Cumulative \\
& & & Percent & Percent \\
\hline \multirow{2}{*}{ Valid } & Tidak Setuju & 2 & 6.7 & 6.7 & 6.7 \\
& Cukup Setuju & 2 & 6.7 & 6.7 & 13.3 \\
& Setuju & 16 & 53.3 & 53.3 & 66.7 \\
& Sangat Setuju & 10 & 33.3 & 33.3 & 100.0 \\
& Total & 30 & 100.0 & 100.0 & \\
\hline
\end{tabular}

Sumber : Hasil jawaban dengan program computer SPSS

Dari pernyataan 2 untuk variabel daya beli (X1) dapat dijelaskan sebagai berikut :

2 responden $(6.7 \%)$ menyatakan tidak setuju

2 responden $(6.7 \%)$ menyatakan cukup setuju

16 responden $(53.3 \%)$ menyatakan setuju

10 responden $(33.3 \%)$ menyatakan sangat setuju

Tabel 3. Pernyataan 3

\begin{tabular}{llrrrr}
\hline & Frequency & Percent & Valid & Cumulative \\
& & & & Percent & Percent \\
\hline \multirow{2}{*}{ Valid } & Tidak Setuju & 1 & 3.3 & 3.3 & 3.3 \\
& Setuju & 16 & 53.3 & 53.3 & 56.7 \\
& Sangat Setuju & 13 & 43.3 & 43.3 & 100.0 \\
& Total & 30 & 100.0 & 100.0 & \\
\hline
\end{tabular}

Sumber : Hasil jawaban dengan program computer SPSS

Dari pernyataan 3 untuk variabel daya beli (X1) dapat dijelaskan sebagai berikut :

1 responden $(3.3 \%)$ menyatakan tidak setuju

16 responden $(53.3 \%)$ menyatakan setuju

13 responden $(43.3 \%)$ menyatakan sangat setuju

2) Analisis Jawaban Responden Terhadap Strategi Pemasaran (Variabel $\mathrm{X}_{2}$ )

Untuk jawaban strategi pemasaran (variabel $\mathrm{X}_{2}$ ) dapat dilihat pada uraian tabel berikut ini:

Tabel 4. Pernyataan 1

\begin{tabular}{rlrrrr}
\hline & Frequency & Percent & $\begin{array}{c}\text { Valid } \\
\text { Percent }\end{array}$ & $\begin{array}{c}\text { Cumulative } \\
\text { Percent }\end{array}$ \\
\hline \multirow{2}{*}{ Valid } & Cukup Setuju & 4 & 13.3 & 13.3 & 13.3 \\
& Setuju & 16 & 53.3 & 53.3 & 66.7 \\
& Sangat Setuju & 10 & 33.3 & 33.3 & 100.0 \\
& Total & 30 & 100.0 & 100.0 & \\
\hline
\end{tabular}

Sumber : Hasil jawaban dengan program computer SPSS

Dari pernyataan nomor 1 untuk variabel strategi pemasaran $\left(\mathrm{X}_{2}\right)$ dapat dijelaskan sebagai berikut : 4 responden $(13.3 \%)$ menyatakan cukup setuju 16 responden $(53.3 \%)$ menyatakan setuju 10 responden $(33.3 \%)$ menyatakan sangat setuju 
Tabel 5. Pernyataan 2

\begin{tabular}{llrrrr}
\hline & Frequency & Percent & $\begin{array}{c}\text { Valid } \\
\text { Percent }\end{array}$ & $\begin{array}{c}\text { Cumulative } \\
\text { Percent }\end{array}$ \\
\hline Valid & Tidak Setuju & 1 & 3.3 & 3.3 & 3.3 \\
& Cukup Setuju & 9 & 30.0 & 30.0 & 33.3 \\
& Setuju & 11 & 36.7 & 36.7 & 70.0 \\
& Sangat Setuju & 9 & 30.0 & 30.0 & 100.0 \\
& Total & 30 & 100.0 & 100.0 & \\
\hline
\end{tabular}

Sumber : Hasil jawaban dengan program computer SPSS

Dari pernyataan nomor 2 untuk variabel strategi pemasaran $\left(\mathrm{X}_{2}\right)$ dapat dijelaskan sebagai berikut: 1 responden $(3.3 \%)$ menyatakan tidak setuju 9 responden $(30.0 \%)$ menyatakan cukup setuju 11 responden $(36.7 \%)$ menyatakan setuju 9 responden $(30.0 \%)$ menyatakan sangat setuju

Tabel 6. Pernyataan 3

\begin{tabular}{llrrrr}
\hline & Frequency & Percent & Valid & Cumulative \\
& & & & Percent & Percent \\
\hline Valid & Tidak Setuju & 1 & 3.3 & 3.3 & 3.3 \\
& Cukup Setuju & 6 & 20.0 & 20.0 & 23.3 \\
& Setuju & 12 & 40.0 & 40.0 & 63.3 \\
& Sangat Setuju & 11 & 36.7 & 36.7 & 100.0 \\
& Total & 30 & 100.0 & 100.0 & \\
\hline
\end{tabular}

Sumber : Hasil jawaban dengan program computer SPSS

Dari pernyataan nomor 3 untuk variabel strategi pemasaran $\left(\mathrm{X}_{2}\right)$ dapat dijelaskan sebagai berikut: 1 responden $(3.3 \%)$ menyatakan tidak setuju 6 responden $(20.0 \%)$ menyatakan cukup setuju 12 responden $(40.0 \%)$ menyatakan setuju 11 responden $(36.7 \%)$ menyatakan sangat setuju

3) Analisis Jawaban Responden Terhadap Peningkatan Hasil Penjualan (Variabel Y) Untuk jawaban peningkatan hasil penjualan (variabel Y), dapat dilihat pada uraian tabel berikut ini:

Tabel 7. Pernyataan 1

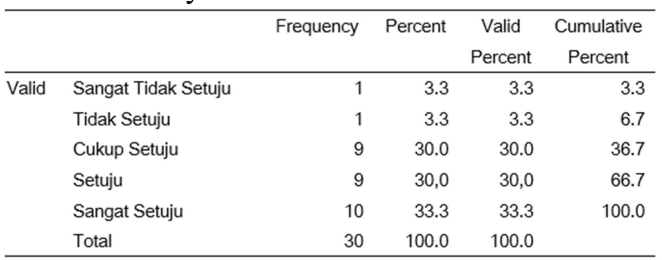

Sumber : Hasil jawaban dengan program computer SPSS

Dari pernyataan nomor 1 untuk variabel hasil penjualan (Y) dapat dijelaskan sebagai berikut :

1 responden $(3.3 \%)$ menyatakan sangat tidak setuju

1 responden (3.3\%) menyatakan tidak setuju

9 responden $(30.0 \%)$ menyatakan cukup setuju

9 responden $(30.0 \%)$ menyatakan setuju

10 responden $(33.3 \%)$ menyatakan sangat setuju
Tabel 8. Pernyataan 2

\begin{tabular}{llrrrr}
\hline & Frequency & Percent & $\begin{array}{c}\text { Valid } \\
\text { Percent }\end{array}$ & $\begin{array}{c}\text { Cumulative } \\
\text { Percent }\end{array}$ \\
\hline Valid & Tidak Setuju & 2 & 6.7 & 6.7 & 6.7 \\
& Cukup Setuju & 4 & 13.3 & 13.3 & 20.0 \\
& Setuju & 10 & 33.3 & 33.3 & 53.3 \\
Sangat Setuju & 14 & 46.7 & 46.7 & 100.0 \\
& Total & 30 & 100.0 & 100.0 & \\
\hline
\end{tabular}

Sumber : Hasil jawaban dengan program computer SPSS

Dari pernyataan nomor 2 untuk variabel hasil penjualan (Y) dapat dijelaskan sebagai berikut : 2 responden $(6.7 \%)$ menyatakan tidak setuju 4 responden (13.3\%) menyatakan cukup setuju 10 responden $(33.3 \%)$ menyatakan setuju 14 responden $(46.7 \%)$ menyatakan sangat setuju

Tabel 9. Pernyataan 3

\begin{tabular}{llrrrr}
\hline & Frequency & Percent & $\begin{array}{r}\text { Valid } \\
\text { Percent }\end{array}$ & $\begin{array}{c}\text { Cumulative } \\
\text { Percent }\end{array}$ \\
\hline Valid & Cukup Setuju & 6 & 20.0 & 20.0 & 20.0 \\
& Setuju & 13 & 43.3 & 43.3 & 63.3 \\
& Sangat Setuju & 11 & 36.7 & 36.7 & 100.0 \\
& Total & 30 & 100.0 & 100.0 & \\
\hline
\end{tabular}

Sumber : Hasil jawaban dengan program computer SPSS

Dari pernyataan nomor 3 untuk variabel hasil penjualan (Y) dapat dijelaskan sebagai berikut : 6 responden $(20.0 \%)$ menyatakan cukup setuju 13 responden $(43.3 \%)$ menyatakan setuju 11 responden $(36.7 \%)$ menyatakan sangat setuju

2. Pembahasan Perhitungan Statistik

a. Uji Validitas terhadap variabel Bebas $\mathrm{X}_{1}$ (Daya Beli)

Hasil uji validitas terhadap variabel $\mathrm{X}_{1}$ (Daya Beli) dapat dilihat pada tabel dibawah ini:

Tabel 10. Hasil Uji Validitas terhadap variabel Bebas $\mathrm{X}_{1}$ (Daya Beli)

\begin{tabular}{cccc}
\hline $\begin{array}{c}\text { No. Butir } \\
\text { Instrumen }\end{array}$ & $\begin{array}{c}\text { Nilai } r \\
\text { hitung }\end{array}$ & $\begin{array}{c}\text { Nilai } \mathrm{r} \text { table } \\
\mathrm{N}=30\end{array}$ & Keterangan \\
\hline 1 & 0.558 & 0.361 & Valid \\
\hline 2 & 0.529 & 0.361 & Valid \\
\hline 3 & 0.549 & 0.361 & Valid \\
\hline 4 & 0.865 & 0.361 & Valid \\
\hline 5 & 0.574 & 0.361 & Valid \\
\hline 6 & 0.582 & 0.361 & Valid \\
\hline 7 & 0.697 & 0.361 & Valid \\
\hline 8 & 0.704 & 0.361 & Valid \\
\hline 9 & 0.687 & 0.361 & Valid \\
\hline 10 & 0.652 & 0.361 & Valid \\
\hline
\end{tabular}

Sumber : Hasil jawaban dengan program computer SPSS

Dari tabel 5.31 diatas, dapat disimpulkan bahwa seluruh instrument variabel daya beli $\left(\mathrm{X}_{1}\right)$ dinyatakan valid, karena ketentuan variabel dinyatakan valid jika nilai $\mathrm{r}_{\text {hitung }}$ yang dihasilkan harus lebih besar dari nilai $r_{\text {tabel }}$ yang telah ditetapkan. 
Tabel 11. Hasil Uji Validitas Butir Instrumen terhadap variabel $\mathrm{X}_{2}$ (Strategi Pemasaran)

\begin{tabular}{cccc}
\hline $\begin{array}{c}\text { No. Butir } \\
\text { Instrumen }\end{array}$ & $\begin{array}{c}\text { Nilai } \mathrm{r} \\
\text { hitung }\end{array}$ & $\begin{array}{c}\text { Nilai } \mathrm{r}_{\text {table }} \\
\mathrm{N}=30\end{array}$ & Keterangan \\
\hline 1 & 0.818 & 0.361 & Valid \\
\hline 2 & 0.727 & 0.361 & Valid \\
\hline 3 & 0.721 & 0.361 & Valid \\
\hline 4 & 0.604 & 0.361 & Valid \\
\hline 5 & 0.544 & 0.361 & Valid \\
\hline 6 & 0.661 & 0.361 & Valid \\
\hline 7 & 0.425 & 0.361 & Valid \\
\hline 8 & 0.487 & 0.361 & Valid \\
\hline 9 & 0.687 & 0.361 & Valid \\
\hline 10 & 0.652 & 0.361 & Valid \\
\hline
\end{tabular}

Sumber : Hasil jawaban dengan program computer SPSS

Dari tabel 5.32 diatas, dapat disimpulkan bahwa seluruh instrument variabel strategi pemasaran $\left(\mathrm{X}_{2}\right)$ dinyatakan valid, karena ketentuan variabel dinyatakan valid jika nilai $\mathrm{r}_{\text {hitung }}$ yang dihasilkan harus lebih besar dari nilai $r$ tabel yang telah ditetapkan.

Tabel 12. Hasil Uji Validitas Butir Instrumen terhadap variabel Y (Hasil Penjualan)

\begin{tabular}{cccc}
\hline $\begin{array}{c}\text { No. Butir } \\
\text { Instrumen }\end{array}$ & $\begin{array}{c}\text { Nilai } r \\
\text { hitung }\end{array}$ & $\begin{array}{c}\text { Nilai } \mathrm{r}_{\text {table }} \\
\mathrm{N}=30\end{array}$ & Keterangan \\
\hline 1 & 0.635 & 0.361 & Valid \\
\hline 2 & 0.569 & 0.361 & Valid \\
\hline 3 & 0.678 & 0.361 & Valid \\
\hline 4 & 0.600 & 0.361 & Valid \\
\hline 5 & 0.701 & 0.361 & Valid \\
\hline 6 & 0.655 & 0.361 & Valid \\
\hline 7 & 0.553 & 0.361 & Valid \\
\hline 8 & 0.660 & 0.361 & Valid \\
\hline 9 & 0.672 & 0.361 & Valid \\
\hline 10 & 0.726 & 0.361 & Valid \\
\hline
\end{tabular}

Sumber : Hasil jawaban dengan program computer SPSS

Dari tabel 5.32 diatas, dapat disimpulkan bahwa seluruh instrument variabel hasil penjualan (Y) dinyatakan valid, karena ketentuan variabel dinyatakan valid jika nilai $\mathrm{r}_{\text {hitung }}$ yang dihasilkan harus lebih besar dari nilai $r$ tabel yang telah ditetapkan.

b. Uji Reliabilitas Instrumen

Pengujian reliabilitas adalah pengujian yang berkaitan dengan masalah adanya kepercayaan terhadap alat test (instrument) variabel yang diteliti. Suatu instrument dapat memiliki tingkat kepercayaan yang tinggi jika hasil dari pengujian instrument tersebut menunjukan hasil yang tetap, adapun uji reliabilitas untuk masing-masing variabel dapat dilihat pada tabel berikut ini:

1) Uji Reliabilitas Variabel Prestasi Kerja $\left(X_{1}\right)$

Tabel 13. Reliability Statistics

\begin{tabular}{cc}
\hline $\begin{array}{c}\text { Cronbach' } \\
\text { S Alpha }\end{array}$ & N of Item \\
\hline 0.828 & 10 \\
\hline
\end{tabular}

Sumber : Hasil jawaban diolah dengan program computer SPSS
Dapat dilihat bahwa untuk variabel daya beli (X1) adalah sebesar 0.828 , dengan nilai $r_{\text {hitung }}$ yang dihasilkan yaitu sebesar 0.828 , sedangkan nilai alpha untuk $\mathrm{N}=30$ sebesar 0.361 sehingga dapat disimpulkan bahwa $r_{\text {alpha }}$ positif dan lebih besar atau $0.828>0.361$. maka dengan demikian instrument prestasi kerja $\left(\mathrm{X}_{1}\right)$ adalah Reliabel.

2) Uji Reliabilitas Variabel Strategi Pemasaran $\left(\mathrm{X}_{2}\right)$

Tabel 14. Reliability Statistics

\begin{tabular}{cc}
\hline $\begin{array}{c}\text { Cronbach' } \\
\text { S Alpha }\end{array}$ & N of Item \\
\hline 0.853 & 10
\end{tabular}

Sumber : Hasil jawaban diolah dengan program computer SPSS

Dapat dilihat bahwa untuk variabel strategi pemasaran $\left(\mathrm{X}_{2}\right)$ adalah sebesar 0.853 , dengan nilai $\mathrm{r}_{\text {hitung }}$ yang dihasilkan yaitu sebesar 0.853 , sedangkan nilai alpha untuk $\mathrm{N}=30$ sebesar 0.361 sehingga dapat disimpulkan bahwa $r_{\text {alpha }}$ positif dan lebih besar atau $0.853>0.361$. maka dengan demikian instrument strategi pemasaran $\left(\mathrm{X}_{2}\right)$ adalah Reliabel.

3) Uji Reliabilitas Variabel Hasil Penjualan (Y) Tabel 15. Reliability Statistics

\begin{tabular}{cc}
\hline $\begin{array}{c}\text { Cronbach' } \\
\text { S Alpha }\end{array}$ & N of Item \\
\hline 0.837 & 10 \\
\hline
\end{tabular}

Sumber : Hasil jawaban diolah dengan program computer SPSS

Dapat dilihat bahwa untuk variabel Hasil Penjualan (Y) adalah sebesar 0.837, dengan nilai $r_{\text {hitung }}$ yang dihasilkan yaitu sebesar 0.837 , sedangkan nilai alpha untuk $\mathrm{N}=30$ sebesar 0.361 sehingga dapat disimpulkan bahwa $r_{\text {alpha }}$ positif dan lebih besar atau $0.837>0.361$. maka dengan demikian instrument Hasil Penjualan (Y) adalah Reliabel.

3. Analisis Untuk Mengetahui Pengaruh Antara $X_{1}$, $\mathrm{X}_{2}$ dan $\mathrm{Y}$

Untuk memudahkan perhitungan, nilai-nilai dalam setiap output SPSS diuraikan sebagai berikut :

1) Deskriptive Statistics

Tabel descriptive statistics menggambarkan nilai rata-rata (mean) persepsi responden terhadap daya beli (variabel independen $\mathrm{X}_{1}$ ), strategi pemasaran (variabel independen $\mathrm{X}_{2}$ ), dan hasil penjualan (variabel independen $Y$ ), standar deviasi (penyimpangan), dan jumlah sample, sebagai berikut:

Tabel 16. Deskriptive Statistics

\begin{tabular}{cccc}
\hline & Mean & Std. Deviation & $\mathrm{N}$ \\
\hline Hasil Penjualan $(\mathrm{Y})$ & 44.3333 & 4.36549 & 30 \\
Daya Beli $\left(\mathrm{X}_{1}\right)$ & 42.0000 & 4.32315 & 30 \\
Strategi Pemasaran $\left(\mathrm{X}_{2}\right)$ & 40.2667 & 4.93358 & 30 \\
\hline
\end{tabular}


UNISTEK, 2018, Edisi 5, No.1

Sumber : Hasil jawaban diolah dengan program computer SPSS

Berdasarkan tabel diatas dapat dijelaskan yaitu nilai mean (rata-rata) persepsi responden terhadap indicator daya beli memiliki mean sebesar 42.0000, standar deviasi 4.32315. Untuk variabel strategi pemasaran memiliki nilai mean sebesar 40.2667, standar deviasi 4,93358. Variabel hasil penjualan memiliki nilai mean sebesar 44.3333, standar deviasi 4.36549.

2) Pengujian Hipotesis

Ketentuan penerimaan dan penolakan hipotesis untuk uji parsial dilakukan dengan uji r, dengan ketentuan sebagai berikut :

a) Jika nilai probabilitas $r_{\text {hitung }}>r_{\text {tabel }}$ tingkat kesalahan sebesar 5\%, maka $\mathrm{H}_{0}$ ditolak dan $\mathrm{H}_{\mathrm{a}}$ diterima.

b) Jika nilai probabilitas $r_{\text {hitung }}<r_{\text {tabel }}$ tingkat kesalahan sebesar 5\%, maka $\mathrm{H}_{0}$ diterima dan $\mathrm{H}_{\mathrm{a}}$ ditolak.

c) Jika nilai probabilitas $\mathrm{F}_{\text {hitung }}>\mathrm{F}_{\text {tabel }}$ tingkat kesalahan sebesar 5\%, maka $\mathrm{H}_{0}$ ditolak dan $\mathrm{H}_{\mathrm{a}}$ diterima.

d) Jika nilai probabilitas $\mathrm{F}_{\text {hitung }}<\mathrm{F}_{\text {tabel }}$ tingkat kesalahan sebesar 5\%, maka $\mathrm{H}_{0}$ diterima dan $\mathrm{H}_{\mathrm{a}}$ ditolak.

Dengan menggunakan perhitungan analisis SPSS versi 12.00 , dapat disimpulkan sebagai berikut :

1) Uji Hipotesis Pengaruh positif antara daya beli dengan hasil penjualan

2) Uji Hipotesis pengaruh positif antara strategi pemasaran dengan prestasi kerja pegawai

3) Uji Hipotesis pengaruh positif antara daya beli dan strategi pemasaran secara bersama-sama (simultan) dengan hasil penjualan

\section{Kesimpulan}

Berdasarkan dari pembahasan pada bab sebelumnya, maka pada bab ini penulis memberikan kesimpulan sebagai berikut :

1. Bahwa daya beli memang mempunyai pengaruh yang positif terhadap hasil penjualan, terbukti dari hasil yang diperoleh bahwa nilai $r_{\text {hitung }}$ lebih besar dari nilai $r_{\text {tabel. }}$.

2. Bahwa strategi pemasaran mempunyai pengaruh positif terhadap hasil penjualan, terbukti dari hasil yang diperoleh bahwa nilai $r_{\text {hitung }}$ lebih besar dari nilai $r_{\text {tabel }}$.

3. Bahwa daya beli dan strategi pemasaran secara bersama-sama (simultan) dapat berpengaruh positif terhadap hasil penjualan, terbukti dari hasil yang diperoleh bahwa nilai $r_{\text {hitung }}$ lebih besar dari nilai $r_{\text {tabel }}$ yang telah ditetapkan.
Daftar Pustaka

Anwar Prabu Mangkunegara, A.A. (2000). Manajemen Sumber Daya Manusia Perusahaan (p. 56). Bandung : Remaja Rosdakarya

Anwar Prabu Mangkunegara, A.A. (2001). Manajemen Sumber Daya Manusia Perusahaan (p. 23). Bandung: Remaja Rosdakarya

Bennet, P.D. (1988). Dictionary of Marketing Terms (p. 72-78) New York : The American marketing association.

Champy, J. (1995). Reengineering Management, The Mandate For New Leadership (p.102-103). New York: Harper Business

D’Aveni, Richard, A. (1994), Hypercompetition, Managing of Dynamic of Strategy Maneuvering (p.65). New York : The Free Press

Daharmesta, B.S. \& dan Handoko, T.H. (1987), Manajemen Pemasaran; Analisis Perilaku Konsumen (p.45). Yogyakarta : Penerbit Liberty

Dolan R.J. (1991). Strategic Marketing Management (p. 86). Boston : Harvard Business School Publications.

Engel JF, et al. (1990). Consumer Behavior, $6^{\text {th }}$ ed (p.5). Chicago : Chicago the Dryden Press

Kotler, P. (1996). Manajemen Pemasaran Analisis Perencanaan Implementasi dan Pengendalian (p.54). Jakarta : Fakultas Ekonomi Universitas Indonesia

Naisbitt, John, \& Aburdene, P. (1985). Reinventing The Corporation (p.76). New York : Warner Books.

Pawitra, T. (1993). Pemasaran : Dimensi Falsafah, Displin dan Keahlian (p.63). Jakarta : Sekolah Tinggi Manajemen Prasetya Mulya 